Slaven Bertoša

\title{
O toleranciji kroz povijest ${ }^{1}$
}

\author{
Pregledni rad \\ Review article
}

UDK 316.647.5(091)

Analizirajući najprije značenje pojma "tolerancija“, a potom i njezine mnogobrojne i različite vrste i definicije, autor ovog priloga donosi pregled najvažnijih znanstvenika i stručnjaka te njihovih radova koje su napisali o spomenutoj temi. Ti se tekstovi odnose na toleranciju kao vrijednost u društvu koje se mijenja, toleranciju kao proces, odnos tolerancije i razine informiranosti, toleranciju u svakodnevnom životu, psihologiju tolerancije, nacionalni identitet $\mathrm{i}$ međunacionalnu toleranciju, odnos tolerancije i ljudskog zajedništva, toleranciju i obrazovanje, toleranciju u politici kulturnog pluralizma, političku kulturu tolerancije kod srednjoškolaca, odgoj za demokratsko građanstvo i toleranciju različitosti i sl. Tolerancijom se bave psiholozi, sociolozi, pedagozi, pravnici, politolozi i, dakako, povjesničari. Bitno je istaknuti činjenicu da o toleranciji kroz prošlost uvijek valja raspravljati u suvremenome multidisciplinarnom pristupu. Danas su vrlo popularne teme o toleranciji mladih te toleranciji unutar demokratskog društva.

Ključne riječi: tolerancija, povijest

1.

Raspravljanje o toleranciji, njezinim oblicima koji jesu ili nisu postojali kroz prošlost, značenjima koja su imali u pojedinim dijelovima svijeta, pa tako i kod nas, valja nedvojbeno usmjeriti na činjenicu da je povijest interdisciplinarna znanost, pa se i pitanje tolerancije $u$ povijesnom kontekstu uvijek promatra na taj način, interdisciplinarno, transdisciplinarno i multidisciplinarno.

Na početku valja postaviti pitanje: Što je uopće tolerancija? U dostupnim informacijama iz rječnika, leksikona, enciklopedija, antropoloških priručnika, na mnogobrojnim internetskim stranicama i sl., pronalazimo podatak da "tolerancija“ (ili „tolerantnost") dolazi od lat. riječi „tolerantia“, odnosno od riječi „tolerare“, koja znači „podnositi, trpjeti i priznavati tuđe mišljenje i uvjerenje“. Tolerancija je, dakle, „trpeljivost, podnošljivost prema tuđim mišljenjima i uvjerenjima“. Tolerantan je onaj koji je „snošljiv, trpeljiv, obziran“. ${ }^{2}$

Postoji više vrsta tolerancije:

- općenito: tolerancija u svakodnevnom životu;

- u društvu: tolerancija različitosti;

Ovaj je tekst pisana verzija izlaganja koje je održano kao uvodno predavanje na Jadranskim susretima studenata povijesti, 27. ožujka 2010. na Filozofskom fakultetu Sveučilišta u Rijeci, Trg Ivana Klobučarića 1.

Usp. primjerice: Klaić 1974: 1342; Garzanti 1981: 940-942; Antiseri 1996. 
- $\quad$ u pedagoškom smislu: tolerancija u školi;

- u medicini: tolerancija na hranu, imunološka tolerancija itd.

Postoji više definicija tolerancije.

Prema filozofskom objašnjenju „tolerancija je stajalište koje se događa u trenutku kada valja otrpjeti 'štetu' koju pojedincu ili skupini nanose drugi pojedinci svojim djelovanjem ili iskazivanjem mišljenja“. Tolerantan je onaj tko je u većini, dok je „štetočinitelj“ onaj tko je u manjini i tko svojim djelovanjem može načiniti „štetu“ većini. No, vrijednost što je „šteta“ i tko je „štetočinitelj“ određuje se, dakako, s pozicija većine.

Prema političkom značenju „tolerancija je odustajanje od primjene sredstava državne, političke, građanske ili pojedinačne prinude protiv iskazanog mišljenja ili djelovanja pojedinca ili skupine“. „,Odustajanje od primjene sredstava prinude“ može imati samo država ili ona skupina ili pojedinac koji je u poziciji političke moći, odnosno moći koju većina ima nad manjinom. Dakle, manjina ne može biti tolerantna prema većini.

UNESCO-va definicija tolerancije glasi: „Tolerancija je poštovanje, prihvaćanje i priznavanje bogatstva različitosti u svim svjetskim kulturama, to je naša forma izražavanja i način da budemo ljudi“. Temelji se na znanju, otvorenosti, komunikaciji i slobodi mišljenja, savjesti i uvjerenju. Tolerancija je sklad u različitostima. Nije samo moralna dužnost, već i politički zahtjev. Tolerancija je vrlina koja mir može učiniti mogućim i koja pridonosi mijenjanju kulture rata u kulturu mira. Tolerancija je aktivno stajalište potaknuto priznanjem univerzalnih ljudskih prava; ona je temeljna sloboda drugih. Trebaju je primjenjivati pojedinci, skupine i države. Tolerancija je odgovornost koja nosi ljudska prava, pluralizam, demokraciju i vladavinu zakona. Dosljedno poštivati ljudska prava, biti tolerantan, znači biti slobodan, čvrsto se držati svojih uvjerenja i prihvaćati da se i drugi drže svojih. To znači prihvaćati činjenicu da su ljudska bića prirodno različita u svojim nastupima, situacijama, govoru, ponašanju i vrijednostima te da imaju pravo živjeti u miru i biti kakvi jesu, a da im drugi ne nameću svoja mišljenja. Generalna skupština UN-a pozvala je 1996. zemlje članice da ustanove Dan tolerancije u skladu s Deklaracijom o principima tolerancije, koju su članice potpisale 16. studenog 1995. Od tada se taj dan smatra međunarodnim "Danom tolerancije“, a „godinom tolerancije“ Generalna skupština UN-a proglasila je 1995.

Obično se pretpostavlja da je tolerancija pojam vezan isključivo za ljudski rod. No, nije tako, jer i kod životinja koje žive u zajednici postoje pravila ponašanja koja valja poštivati, pa se zaključuje da snošljiv odnos prema drugom biću pogoduje preživljavanju jedinki.

Toleranciju uvijek promatramo u odnosu na njezinu suprotnost - netoleranciju. Zato se i kaže da je ljudska vrsta obilježena sklonošću za snošljivo i nesnošljivo ponašanje. Oba ova oblika ponašanja mogu se lako i brzo naučiti i usvojiti, zbog čega su odgojitelji (najčešće roditelji) odgovorni za stupanj tolerancije ili netolerancije koji pokazuju njihova djeca. $U$ odgojnom smislu, djeca toleranciju uče opažajući je najprije u ponašanju svojih roditelja, a potom je proširujući i na druge ljude, izvan obitelji. Zbog toga je u odgoju potrebno ne poticati stereotipe i predrasude prema onome što se razlikuje od obiteljskih stajališta i vrijednosti.

Tolerancija prema drugim ljudima temeljni je uvjet za razvoj društva. Pri tome valja smatrati da ono što mi mislimo ili cijenimo nije nužno bolje od onoga što misle i cijene drugi ljudi. Ponekad nam se bogatstvo kulturnih i bioloških raznolikosti svijeta predstavlja kao nepremostiva razlika, iako su društvene i kulturne različitosti između pojedinih društava i kultura često manje nego one između društvenih skupina unutar jednog društva ili kulture.

Upoznajući druge ljude, različite od nas samih, uočavamo drukčiju logiku pogleda na stvari, a razumijevajući drukčije vrednovanje stvarnosti postajemo bogatiji, jer novo znanje pridonosi da bolje razumijemo sami sebe. Raznolikost je ljudsko bogatstvo, jer učeći o 
drugima postajemo tolerantni prema onome što je različito. Edukacija vodi toleranciji, a tolerancija vodi životu u zajednici u kojoj se različitosti prožimaju na takav način da izgrađuju povjerenje. Internet kao sredstvo edukacije svakako je sredstvo izgradnje opće ljudske tolerancije, iako krije i mnoge opasnosti netolerancije.

$\mathrm{U}$ čitavom je svijetu, pa tako i kod nas, već spomenuta naglašena potreba za multidisciplinarnim pristupima istraživanju raznih tema dovela do postojanja vrlo opsežnih radova i o pitanju tolerancije. ${ }^{3}$

Teorijskim razmatranjima o toleranciji u Hrvatskoj bavili su se, između ostalih, psiholozi Mirjana Krizmanić [tolerancija kao vrijednost u društvu koje se mijenja (Krizmanić 2010), tolerancija kao proces, odnos tolerancije i razine informiranosti (Krizmanić 2005; Krizmanić 1997: 50-54; Krizmanić-Kolesarić 2004)], Vladimir Kolesarić [tolerancija u svakodnevnom životu, psihologija tolerancije (Krizmanić-Kolesarić 2005)] i Dinka Čorkalo Biruški [nacionalni identitet i međunacionalna tolerancija (Čorkalo 1999)]; sociolozi Nikola Skledar [tolerancija i ljudsko zajedništvo (Skledar 1996: 293-306)] i Jadranka Čačić-Kumpes [obrazovanje i tolerancija, tolerancija u politici kulturnog pluralizma (Čačić-Kumpes 1996: 307-319; ČačićKumpes 1998: 71-83)]; pravnik Gojko Bežovan [pravni aspekti proučavanja civilnog društva u RH (Bežovan 2005; Bežovan-Zrinščak 2007)]; pedagoginja Sofija Vrcelj [odgoj za toleranciju (Vrcelj 1996)]; politolog Berto Šalaj [politička kultura tolerancije kod srednjoškolaca, odgoj za demokratsko građanstvo i tolerancija različitosti (Šalaj 2011)] te mnogi drugi stručnjaci.

Kao rezultat posebnog projekta pod pokroviteljstvom Ministarstva znanosti, obrazovanja i športa Republike Hrvatske nastao je suvremeni priručnik za odgojitelje, učitelje, stručne suradnike i roditelje o toleranciji kroz pedagoško gledište preko priča cijenjene hrvatske spisateljice Ivane Brlić-Mažuranić (Ogulin, 18. IV. 1874. - Zagreb, 21. IX. 1938.) (Dobranović et al. 2010). Ističem i zbornik radova o toleranciji unutar demokracije, u kojem se obrazlaže kako se demokracija manifestira putem aktivnoga građanstva i na taj način gradi demokratsko društvo (Broz 2007).

Za ovu prigodu najznačajniji su, dakako, povjesničari: ponajprije Miroslav Bertoša [suživot mletačkih i austrijskih podanika u Istri od XVI. do XVIII. stoljeća (Bertoša 1982: 99-127; 1983: 237-292; 1985: 76-97; 1988: 7-26; 1989: 25-36; 1994: 195-202; 1999: 43-57; 2004: 127156; 2005: 421-441; 2005a: 117-121; 2006: 15-32; 2008: 33-42; 2009: 439-445)]', Drago Roksandić [odnos etnosa, konfesije i tolerancije i kulturni identiteti na našim prostorima (Roksandić 2004)]; metodičar Ivo Rendić-Miočević [tolerancija u analizi pitanja hrvatskog identiteta (Rendić-Miočević 2006)]; Lovorka Čoralić (tolerancija u višestoljetnim hrvatskomletačkim kontaktima) ${ }^{5}$; Hrvoje Petrić [tolerancija i netolerancija prema pravoslavnim Vlasima na području Koprivnice u XVII. stoljeću (Petrić 2006)] i Tea Perinčić (Mayhew) [tolerancija u praksi na temelju podataka iz apostolskih vizitacija veronskog biskupa Agostina Valiera 1579., na primjeru Raba (Perinčić 1998; 2004)].

2.

Što se tiče pojedinih primjera o toleranciji tijekom prošlosti, kojih također ima vrlo mnogo, ovdje bih se ograničio na samo njih nekoliko najkarakterističnijih i/ili najpoznatijih.

Prema mišljenju američkog židovskog filozofa Michaela Walzera (New York, 1935.), professora emeritusa na Institute for Advanced Study u Princetonu i autora mnogobrojnih

3 Između ostalog, ovdje izdvajam tematski broj časopisa Društvena istraživanja, vol. 5, br. 2 (22), Zagreb 1996., posvećen temi „Tolerancija i suvremenost“, u izdanju zagrebačkog Instituta za društvena istraživanja "Ivo Pilar“. Iz opsežne autorove bibliografije o toj temi, na ovom su mjestu izdvojeni samo neki radovi.

5 Od mnogobrojnih autoričinih radova u kojima nalazimo niz podataka i detalja o toleranciji ovdje izdvajam: Čoralić 2001, Čoralić 2001a, Čoralić 2003. 
knjiga o pravednim i nepravednim ratovima, nacionalizmu, gospodarskoj pravdi i toleranciji, valja razlikovati pet režima tolerancije. ${ }^{6}$

Multinacionalno carstvo. Stara Perzija, ptolomejski Egipat, stari Rim i Osmansko Carstvo primjeri su modela tolerancije na temelju nacionalno-vjerskih razlika. U njima se tolerira nekoliko nacionalno-vjerskih skupina, ali ne i pojedinci kao takvi, a pripadnost nekoj skupini je obvezatna. Carskom vlašću skupine su prisiljene na međusobnu trpeljivost. Takav je sustav djelotvorno mogao funkcionirati dugo vremena. lako je državna vjera bio islam, u istoj su državi zajedno živjele grčko-pravoslavne, armensko-pravoslavne i židovske zajednice. Bilo im je dopušteno osnivati autonomne organizacije.

Međunarodno društvo država. Ono predstavlja slab režim tolerancije. Na jednom kraju ima načelo suvereniteta, a na drugom pravnu doktrinu tzv. humanitarne intervencije. Međunarodna zajednica takve države tolerira, a njihovi državnici najčešće nisu skloni snositi posljedice svojih intervencija, pa njihovu težinu prebacuju na diplomaciju. Svrha vojne intervencije nije uvođenje ili provođenje demokracije, nego isključivo zaštita ljudskih života. Intervencija uvijek mora biti dragovoljna. Vijetnamska intervencija u Kambodži 1979., s ciljem zaustavljanja djelovanja Crvenih Kmera, jedan je od takvih primjera.

Sudruštva ili konsocijacije. To su države dvaju ili triju naroda. Belgija, Cipar, Švicarska, Libanon, Bosna i Hercegovina primjeri su ovog režima tolerancije. U njima različite skupine moraju tolerirati jedna drugu. Određeni elementi, poput zajedničke povijesti, moraju biti uređeni na razini ustava, ali bez ikakve pomoći izvana. U raspodjeli ovlasti i novca koji će se trošiti na javne službe i fondove mora postojati ravnoteža, a sve treba biti podređeno ideji „približne jednakosti“. Ako se uspostavljanje konsocijacije dogodi prije nastanka snažnih nacionalnih pokreta, kao primjerice u Belgiji i Švicarskoj, mogućnosti uspjeha su velike. Međutim, ako se povjerenje između skupina izgubi i ako propadnu institucionalni dogovori, što se dogodilo na Cipru i u Libanonu, međusobna tolerancija postaje vrlo ugrožena. Kod skupina uvijek postoji strah da će se konsocijacija pretvoriti u naciju-državu te da će jedna od skupina biti proglašena manjinom. $U$ trenucima krize najvažnije je prilagoditi se u pitanjima jezika, raspodjele ovlasti, parlamentarne zastupljenosti i financiranja.

Države-nacije. Ovdje se fokus pitanja tolerancije sa skupine prebacuje na pojedinca. Nacija-država stvara homogeni kulturni prostor, zajedničku povijest i zajednički jezik, koji nadziru državne akademije. Obrazovanje ima važnu ulogu u garanciji kulturne obnove društva. Oni koji se ne prilagode standardnoj kulturi, toleriraju se na temelju svojeg statusa manjine. Dopušteno im je imati vlastitu vjeru, učiti vlastitu povijest i držati se običaja svojih predaka. Ali, nacija-država na sve to gleda s dozom sumnje. Liberalna nacija-država jamči jednaka prava i jednako ponašanje prema svima. No, u pokušajima zaštite tolerancije rezultati su ambivalentni. $\mathrm{S}$ jedne strane, čak je i u liberalnim nacijama-državama manje „mjesta za razliku“ nego u multinacionalnim carstvima ili u konsocijacijama, a mnogo manje nego u državama s više nacija. S druge strane, nacija-država proizvodi paradoks koji ne može ignorirati niti jedna teorija tolerancije: nacija-država manje je tolerantna prema skupinama, ali ih ipak prisiljava da one budu tolerantnije prema pojedincima.

Imigracijska društva. U njima se briga nacije-države za pojedinca povećava. Imigracijsko društvo ne poznaje sumnju koju prema kulturnim skupinama pokazuje nacija-država. $S$ obzirom na činjenicu da imigracijskom društvu nedostaje etnička homogenost njegovih članova, ono po svojoj prirodi potiče toleranciju. U imigracijskom se društvu niti jednoj skupini ne dopušta da se nameće drugima, da preuzme kontrolu nad javnim prostorom ili ovlada javnim resursima. Odbacuje se svaki oblik korporacije. Nadalje, država je neutralna u

Od autorove opsežne bibliografije o navedenim temama ovdje izdvajam: Walzer 1970, Walzer 1983, Walzer 1995, Walzer 1996, Walzer 1997. 
pogledu kultura pojedinih skupina, ali ih sve podupire. Većina ljudi u imigracijskom društvu nosi dvojni ili podijeljeni identitet na temelju kulturnih i političkih karakteristika. Tako, primjerice, u SAD-u postoje talijanski, poljski, njemački, kineski i dr. Amerikanci.

\section{3.}

U mnogim se gradovima tolerancija poštivala kao „vrlina“. Veliki su gradovi, od antičkog razdoblja, preko srednjeg i novog vijeka, do suvremenog doba, oduvijek bili mjesta u koja su se sklanjali disidenti, nevjernici i prognanici. Srednjovjekovni su gradovi Zapada hodočasnicima na putu za Rim pružali dobrodošlicu na jednak način kako su to činili i orijentalni gradovi za muslimanske hodočasnike u Meku. No, u povijesnim zapisima postoje i podaci o progonima Židova u srednjovjekovnim gradovima u Njemačkoj, u Veneciji, kasnije i u Rusiji.

Tijekom prošlosti bilo je doneseno više uredaba o vjerskoj toleranciji. ${ }^{7}$ Edikt iz 311. godine u Nikomediji je proglasio rimski car Galerije. Njime je oprost dao kršćanima koji se nisu pokoravali drevnim običajima. Namjera edikta bila je uspostavljanje slobode vjerskog izražavanja u Rimskom Carstvu, kako bi se postigao unutarnji politički mir. No, tek je 380. godine, uredbom cara Teodozija I., kršćanstvo postalo državnom religijom u Rimskom Carstvu.

Ubrzo je uslijedio i Milanski edikt iz 313. godine, koji su zajednički proglasili Konstantin I. Veliki, tetrarh Zapada, i Licinije, tetrarh Istoka. Njime je i službeno označen završetak vjerskih progona u Rimskom Carstvu.

Za povijest tolerancije na crkvenom planu osobito značenje ima Augsburški vjerski mir iz 1555. Predstavlja ugovor između njemačkog cara Karla V. i snaga Schmalkaldenske lige, saveza luteranskih kneževa, kojim su službeno završeni vjerski sukobi. Mir je utvrdio princip „cuius regio eius et religio", čime su njemački kneževi, svaki u svojoj državi, mogli odrediti vjeru svojih podanika, katoličku ili luteransku, a svi koji se s time nisu slagali dobili su mogućnost emigrirati.

U novovjekovnom je periodu od osobitog značenja bio i Edikt iz Torde u Transilvaniji, koji predstavlja pokušaj jamstva vjerske slobode u kršćanskoj Europi. Tijekom sabora 1568. proglasio ga je ugarski kralj (priznat samo od Osmanlija) i erdeljski knez Ivan II. Žigmund Zapolja (sin Ivana Zapolje, dvojnog kralja) i to na poticaj Dávida Ferenca, unitarijanskog propovjednika i utemeljitelja reformatorske crkve u Transilvaniji. Odnosio se samo na četiri vjerske skupine: katolike, kalviniste, luterane i unitarijance [oni vjeruju u jedinstvenost Boga, suprotno tradicionalnom kršćanskom vjerovanju u Trojstvo (Otac, Sin i Sveti Duh); vjeruju u moralni autoritet, ali ne i božansku prirodu Isusa].

Kralj Henrik IV. svojim je nekadašnjim istomišljenicima 1598. izdao Nanteski edikt, kojim je hugenotima zajamčio slobodu vjere i time konačno doveo do završetka dugotrajnih vjerskih sukoba u Francuskoj.

Vjerska tolerancija, nastala kao reakcija na sukobe tijekom znamenitog Tridesetogodišnjeg rata (1618.-1648.) i 80-godišnjeg rata između Španjolske i Republike Sedam Ujedinjenih Pokrajina (1568.-1648.), proglašena je Westfalijskim mirom iz 1648. Tim je važnim dogovorom, koji se smatra prvim modernim diplomatskim kongresom, utvrđen novi europski politički sustav, temeljen na koncepciji suverene države kojom upravlja vladar. Potvrđene su odredbe Augsburškog mira iz 1555., a katoličkoj i luteranskoj vjeri sada je pridodana i priznata i ona kalvinistička.

O ovim općepoznatim odredbama i zakonima podrobnije podatke nalazimo u enciklopedijama, priručnicima i udžbenicima. Usp., primjerice: Ilustrirana povijest 1974-1979, Saitta 1978-1980, History 1986, Povijest svijeta 1990, Povijest svijeta 2002, Encyclopedia 2002, Bertoša, S. 2004, Povijest svijeta 2007, llustrirana enciklopedija 2008. 
Za Habsburšku Monarhiju, a time i naše krajeve koji su joj pripadali, vrlo je značajan bio Edikt o vjerskoj toleranciji, pravni akt koji je 21. prosinca 1781. izdao car i kralj Josip II., sin Marije Terezije. Vladar je tim činom sve kršćanske vjere u državi po statusu izjednačio s Katoličkom crkvom. Omogućio je potpunu vjersku slobodu luteranima, kalvinistima, pravoslavnima i Židovima, a to je najviše učinio zbog želje za ograničavanjem moći i autonomija Katoličke crkve, koje njegovoj apsolutističkoj i centralističkoj državi nisu odgovarale. U sklopu donesenih mjera Katoličku crkvu je podvrgao državnom nadzoru, ukinuo je niz crkvenih redova i oko 700 samostana, posebice onih koji se nisu isticali aktivnim sudjelovanjem u odgoju i njezi bolesnika. Međutim, tada su bili ukinuti i neki crkveni redovi koji su mnogo radili na prosvjećivanju žiteljstva, poput benediktinaca i pavlina, kojima su odgoj i obrazovanje spadali u glavne djelatnosti. Pod pritiskom javnosti, prije svoje smrti Josip II. morao je ukinuti mnoge reforme koje je bio proveo, ali ovaj je edikt ostao na snazi i dalje.

U velikim promjenama koje je svijet doživio u drugoj polovici XVIII. stoljeća važno je spomenuti dvije deklaracije: američku „Deklaraciju o pravima“, koju je u lipnju 1776. proglasilo plemstvo Virginije i kojom je puritanski princip slobode spojen s prosvjetiteljskom demokracijom, te francusku „Deklaraciju o pravima čovjeka“, koja je 1789., u 17 članaka, sintetizirala konačnu propast „,starog sustava“ i proglasila nove principe koji od tada reguliraju javni život Francuza. Obje se temelje na vrlo naglašenom načelu tolerancije.

Istom stoljeću pripadaju i znamenite misli i ideje o toleranciji koje ističu francuski filozof, teoretičar i književnik François-Marie Arouet, poznatiji kao Voltaire (Pariz, 21. studenoga 1694. - Pariz, 30. svibnja 1778.) (Voltaire 1997) te engleski filozof i pisac, utemeljitelj klasičnog britanskog empirizma John Locke (Wrington, 29. kolovoza 1632. - Oates, 28. listopada 1704.) (Locke 1995), čiji se tekstovi smatraju temeljem suvremene demokracije.

Tolerancija, dakako, može imati i neke druge oblike. Primjerice, Istočno-indijska je kompanija dugo vremena tolerirala "sati“ (samospaljivanje indijske udovice na pogrebnoj lomači svojeg muža), a britanska je kolonijalna vlast taj običaj zabranila tek 1829.

4.

Opisujući stanje u Europskoj uniji, Walzer navodi da njezina dinamika vodi u smjeru imigracijskog društva, što će njezinim članicama donijeti i prednosti i nedostatke multikulturalizma, htjele to one ili ne. U pogledu stanovništva, svaka će država članica postati heterogenija nego što jest. Slabljenje pojedinih nacija-država $i$ istodobno jačanje središnje vlasti podržava regionalnost, ali dovodi i do toga da pojedinac gubi vezu sa svojom regionalnom nacionalnošću. Takve tendencije povećat će vjerojatnost velikih migracija, pa će se „većinske nacije“ uskoro naći u situaciji da žive s „manjinama“ na koje nisu naviknute. EU će kao cjelina od svojih članica morati tražiti više tolerancije, odnosno toleranciju drukčiju od one nekadašnje.

I niz tema različitih znanstvenih skupova, domaćih i međunarodnih, često je povezan s problematikom tolerancije u mnogim segmentima javnog, političkog i kulturnog života na nekom području, pa tako i u krajevima na istočnoj obali Jadranskoga mora. Tematika o kojoj raspravljamo, uz povijesnu, ima i aktualnu dimenziju, pa će se Europa u konstituiranju još dugo trebati baviti dramatičnim posljedicama tolerancije i netolerancije na prostorima Staroga kontinenta. 


\section{POPIS LITERATURE}

\section{ANTISERI 1996}

Dario Antiseri, La tolleranza e i suoi nemici, prefazione di Giorgio de Finis, Roma 1996.

\section{BERTOŠA 1982}

Miroslav Bertoša, „L'equilibrio nel processo di acculturazione in Istria: tra interazioni e opposizioni (Ipotesi di lavoro preliminari: un esempio dell'Istria meridionale)", Atti del Centro di Ricerche Storiche, vol. XII, Trieste-Rovigno 1982., 99-127 (I. dio).

\section{BERTOŠA 1983}

Miroslav Bertoša, „L'equilibrio nel processo di acculturazione in Istria: tra interazioni e opposizioni (Ipotesi di lavoro preliminari: un esempio dell'Istria meridionale)", Atti del Centro di Ricerche Storiche, vol. XIII, 1983., 237-292 (II. dio).

\section{BERTOŠA 1985}

Miroslav Bertoša, „Istarsko akulturacijsko ravnotežje druge polovice XIX. stoljeća", u: Istarski preporoditelj Juraj Dobrila (1812.-1882.), Pazin 1985., 76-97.

\section{BERTOŠA 1988}

Miroslav Bertoša, „Migracije i antagonističke grupe: Starosjedioci i doseljenici između sukoba i suživota (Odrednice „istarskog modela“ od XVI. do XVIII. stoljeća)", Jugoslovenski istorijski časopis, XXIII, 3-4, Beograd 1988., 7-26.

\section{BERTOŠA 1989}

Miroslav Bertoša, „I 'travagli' di una convivenza difficile: 'habitanti vecchi' e 'habitanti novi' nell'Istria veneta dal XVI al XVIII secolo", u: Popoli e culture in Istria: interazioni e scambi, Atti del Convegno di Muggia, 20-21 novembre 1987. Serie Quaderni V, Circolo di Cultura IstroVeneta „Istria“, Trieste 1989., 25-36.

\section{BERTOŠA 1994}

Miroslav Bertoša, „Istarski pabirci o kolonizaciji, etnocentrizmu, integraciji i dezintegraciji (XVI.-XVIII. stoljeće)", Gazophylacium - Časopis za znanost, umjetnost, gospodarstvo i politiku, I, 3-4, Zagreb 1994., 195-202.

\section{BERTOŠA 1999}

Miroslav Bertoša, „Teritorijalno-gospodarski prijepori i međunarodno dogovaranje: jedan primjer srednjovjekovne diplomacije", Zbornik Diplomatske akademije, god. IV., br. 2, Zagreb 1999., 43-57.

\section{BERTOŠA 2004}

Miroslav Bertoša, „,Pastori dell'herbadego' nelle ,differentie' veneto-arciducali“, Atti del Centro di Ricerche Storiche, vol. XXXIV, Trieste - Rovigno 2004., 127-156.

\section{BERTOŠA 2005}

Miroslav Bertoša, „Transhumancije i granice. Gospodarski život i granične napetosti na istarskome sjeveru (mikropovijesna epizoda iz 1571.-1572.)“, u: Raukarov zbornik: zbornik u čast Tomislava Raukara, ur. Neven Budak, Zagreb, FF Press, 2005., 421-441.

\section{BERTOŠA 2005A}

Miroslav Bertoša, „Stočarski sukobi u XVI. stoljeću: o 'presađivanju' granice i 'kolčanju' međa na planini Dober dol na Ćićariji 1572. godine", Kalendar Franina i Jurina, Račice 2005., 117121.

\section{BERTOŠA 2006}

Miroslav Bertoša, „U znaku plurala: višebrojni i višeslojni identiteti istarski (Kroki ranoga novovjekovlja XVI.-XVIII. stoljeća)“, u: Identitet Istre - ishodišta i perspektive (ured. Marino Manin et al.), Zagreb, Institut društvenih znanosti „Ivo Pilar" - Zagreb, Hrvatski institut za povijest Zagreb, Centar za promicanje socijalnog nauka crkve HBK - Zagreb, Filozofski fakultet u Puli, 2006., 15-32.

\section{BERTOŠA 2008}

Miroslav Bertoša, „The European Paradox of Croatia: Integrative 'Disintegrations' of the XVI and XVIII Centuries", Croatian Studies Review / Časopis za hrvatske studije, vol. 5., Split-Sydney-Waterloo-Zagreb 2008., 33-42.

\section{BERTOŠA 2009}

Miroslav Bertoša, „Zveket mačeva, društvene krize i mentalni senzibiliteti. Povijesni okviri nekih odrednica od 16. do 18. stoljeća“, u: Sedam- 
naest stoljeća zadarske crkve. Zbornik radova znanstvenog skupa o 1700. obljetnici mučeništva Sv. Stošije (Anastazije), 16.-18. studenog 2004., sv. 1., Zadar 2009., 439-445.

\section{BERTOŠA, S. 2004}

Slaven Bertoša, Svjetska povijest modernog doba (XVI.-XIX. stoljeće) s posebnim osvrtom na Apeninski poluotok, Zagreb 2004.

\section{BEŽOVAN 2005}

Gojko Bežovan, Civilno društvo, Zagreb 2005.

\section{BEŽOVAN-ZRINŠČAK 2007}

Gojko Bežovan - Siniša Zrinščak, Civilno društvo u Hrvatskoj, Zagreb 2007.

\section{BROZ 2007}

Obje strane demokracije, uredila Tajana Broz, Zagreb 2007.

\section{ČAČIĆ-KUMPES 1996}

Jadranka Čačić-Kumpes, „Obrazovanje i tolerancija", Društvena istraživanja; časopis za opća društvena pitanja, vol. 5, br. 2 (22), Zagreb 1996., 307-319.

\section{ČAČIĆ-KUMPES 1998}

Jadranka Čačić-Kumpes, „Etničke raznolikosti u Europi i politika kulturnog pluralizma" u: Etničnost, nacija, identitet: Hrvatska i Europa, ur. Ružica Čičak-Chand i Josip Kumpes, Zagreb 1998., 71-83.

\section{ČORALIĆ 2001}

Lovorka Čoralić, U gradu svetoga Marka: povijest hrvatske zajednice u Mlecima, Zagreb 2001.

\section{ČORALIĆ 2001A}

Lovorka Čoralić, Hrvati u procesima mletačke inkvizicije, Zagreb 2001.

\section{ČORALIĆ 2003}

Lovorka Čoralić, Hrvatski prinosi mletačkoj kulturi: odabrane teme, Zagreb 2003.

\section{ČORKALO 1999}

Dinka Čorkalo et al. (ur.), Nacionalni identitet $i$ međunarodna tolerancija, Zagreb 1999.

\section{DOBRANOVIĆ ET AL. 2010}

Mirjana Dobranović - Anka Došen-Dobud Heda Gospodnetić - Ljiljana Ivković - Smiljana Kovač-Prugovečki, $K$ toleranciji: priče Ivane $B r$ lić-Mažuranić kao poticaj razvoju tolerancije: priručnik za odgajatelje, stručne suradnike, studente učiteljskih i srodnih fakulteta i roditelje, Zagreb 2010.

\section{ENCYCLOPEDIA 2002}

Encyclopedia of World History, Bath 2002.

\section{GARZANTI 1981}

Enciclopedia Garzanti di filosofia e epistemologia, logica formale, linguistica, psicologia, psicoanalisi, pedagogia, antropologia culturale, teologia, religioni, sociologia, Milano 1981.

\section{HISTORY 1986}

History of the World: the Last Five Hundred Years, ur. Esmond Wright, New York 1986.

\section{ILUSTRIRANA ENCIKLOPEDIJA 2008}

Ilustrirana enciklopedija svjetske povijesti za mlade, prijevod i lektura Drago Štajduhar, Split 2008.

\section{ILUSTRIRANA POVIJEST 1974-1979}

Velika ilustrirana povijest svijeta, izvorno izdanje pripremili Gérard Du Ry van Beest Holle i suradnici, Rijeka 1974.-1979.

\section{KLAIĆ 1974}

Bratoljub Klaić, Veliki rječnik stranih riječi, Zagreb 1974.

\section{KRIZMANIĆ 1997}

Mirjana Krizmanić, „Tolerancija kao proces: obnova socijalnog života na oslobođenim područjima Republike Hrvatske“, Erasmus, br. 21, Zagreb 1997., 50-54.

\section{KRIZMANIĆ 2005}

Mirjana Krizmanić, „Tolerancija kao vrijednost", XIII. godišnja konferencija hrvatskih psihologa: Vrijednosti, odgovornost i tolerancija u društvu koje se mijenja, sažetak predavanja, Osijek 2005.

\section{KRIZMANIĆ 2010}

Mirjana Krizmanić, Život s različitima, Zagreb 2010. 


\section{KRIZMANIĆ-KOLESARIĆ 2004}

Mirjana Krizmanić - Vladimir Kolesarić, „Razina informiranosti i tolerancija“, u: XIV. dani psihologije u Zadru, 26.-29. svibnja 2004.: međunarodni znanstveno-stručni skup, sažeci radova, ur. Vera Ćubela Adorić, Ilija Manenica i Zvjezdan Penezić, Zadar 2004.

\section{KRIZMANIĆ-KOLESARIĆ 2005}

Mirjana Krizmanić - Vladimir Kolesarić, Tolerancija u svakodnevnom životu: psihologija tolerancije, Jastrebarsko 2005.

\section{LOCKE 1995}

John Locke, Lettera sulla tolleranza: per convivere da cittadini del mondo, traduzione e presentazione di Bettina Della Casa, Bussolengo 1995.

\section{PERINČIĆ 1998}

Tea Perinčić, „Prilog istraživanju apostolskih vizitacija Agostina Valiera u dalmatinskim i istarskim biskupijama“, Povijesni prilozi, br. 17, Zagreb 1998., 157-176.

\section{PERINČIĆ 2004}

Tea Perinčić, Rapska biskupija u vizitaciji Augustina Valiera 1579. godine, magistarski rad, Filozofski fakultet, Odsjek za povijest, Zagreb 2004.

\section{PETRIĆ 2006}

Hrvoje Petrić, „Katolička obnova i konfesionalne tolerancije / netolerancije na širem prostoru Triplex Confiniuma do oko 1630. godine: primjer grada Koprivnice", Croatica Christiana Periodica, br. 57, Zagreb 2006., 55-63.

\section{POVIJEST SVIJETA 1990}

Povijest svijeta: od početka do danas, prevela Alka Škiljan, Zagreb 1990.

\section{POVIJEST SVIJETA 2002}

Povijest svijeta, uredio Geoffrey Barraclough, Zagreb 2002.

\section{POVIJEST SVIJETA 2007}

Povijest svijeta: velika obiteljska enciklopedija, ur. Ivanka Borovac, Zagreb 2007.

\section{RENDIĆ-MIOČEVIĆ 2006}

Ivo Rendić-Miočević, Hrvatski identitet - traj- nost i fluidnost: usporedba Kvarnera i gorske Dalmacije, Rijeka 2006.

\section{ROKSANDIĆ 2004}

Drago Roksandić, Etnos, konfesija, tolerancija, Zagreb 2004.

\section{SAITTA 1978-1980}

Armando Saitta, II cammino umano, vol. 1-3, Bologna 1978.-1980.

\section{SKLEDAR 1996}

Nikola Skledar, „Tolerancija kao nužni uvjet ljudskog zajedništva i dostojanstva", Društvena istraživanja; časopis za opća društvena pitanja, vol. 5, br. 2 (22), Zagreb 1996., 293-306.

\section{ŠALAJ 2011}

Berto Šalaj, „Politička pismenost mladih u Hrvatskoj", u: Odgaja li škola dobre građane, ur. Dragan Bagić, Zagreb 2011.

\section{VOLTAIRE 1997}

Voltaire, Rasprava o toleranciji, priredio Milivoj Solar, prevela Bosiljka Brlečić, Zagreb 1997.

\section{VRCELJ 1996}

Sofija Vrcelj, „Žena u društvu i odgoj za toleranciju“, u: Obrazovanje za tolerantnost; pristupi, koncepcije i rješenja, Rijeka 1996.

\section{WALZER 1970}

Michael Walzer, Obligations: Essays on Disobedience, War and Citizenship, London 1970.

\section{WALZER 1983}

Michael Walzer, Spheres of Justice: a Defence of Pluralism and Equality, New York 1983.

\section{WALZER 1995}

Michael Walzer, Pluralism, Justice and Equality, New York 1995. (koautor David Miller).

\section{WALZER 1996}

Michael Walzer, Toward a Global Civil Society, Providence 1996.

\section{WALZER 1997}

Michael Walzer, On Toleration, New HavenNew York 1997. 


\section{SAŽETAK}

Analizirajući najprije značenje pojma "tolerancija“, a potom i njezine mnogobrojne i različite vrste i definicije, autor ovog priloga donosi pregled najvažnijih znanstvenika i stručnjaka te njihovih radova koje su napisali o spomenutoj temi. Ti se tekstovi odnose na toleranciju kao vrijednost u društvu koje se mijenja, toleranciju kao proces, odnos tolerancije i razine informiranosti, toleranciju u svakodnevnom životu, psihologiju tolerancije, nacionalni identitet i međunacionalnu toleranciju, odnos tolerancije i ljudskog zajedništva, toleranciju i obrazovanje, toleranciju u politici kulturnog pluralizma, političku kulturu tolerancije kod srednjoškolaca, odgoj za demokratsko građanstvo i toleranciju različitosti i sl. Tolerancijom se bave psiholozi, sociolozi, pedagozi, pravnici, politolozi i, dakako, povjesničari. Bitno je istaknuti činjenicu da o toleranciji kroz prošlost uvijek valja raspravljati u suvremenome multidisciplinarnom pristupu. Danas su vrlo popularne teme o toleranciji mladih te toleranciji unutar demokratskog društva.

\section{RIASSUNTO}

\section{Sulla tolleranza nella storia}

Analizzando dapprima il significato del termine tolleranza, poi anche le sue numerose e diverse accezioni e definizioni, l'autore delinea un quadro dei più importanti scienziati ed esperti che si sono espressi sull'argomento, passando in rassegna i saggi da essi pubblicati sul tema in questione. Tali saggi toccano aspetti quali la tolleranza come valore nelle società in mutamento, la tolleranza come processo, il rapporto tra tolleranza e livello di conoscenza, la tolleranza nella vita quotidiana, la psicologia della tolleranza, la relazione tra identità nazionale e tolleranza internazionale, il rapporto tra tolleranza e collettività umana, nonché fra tolleranza ed educazione, la tolleranza nella politica del pluralismo culturale, la cultura politica della tolleranza ed il suo insegnamento agli studenti delle scuole medie e medie superiori, l'educazione alla cittadinanza democratica e alla tolleranza delle diversità, ecc. Di tolleranza si occupano psicologi, sociologi, pedagoghi, giuristi, politologi e, naturalmente, anche storici. È importante sottolineare il fatto che il tema della tolleranza nel corso dell'evoluzione storica va sempre trattato attraverso un moderno approccio multidisciplinare. Oggigiorno sono ampiamente dibattuti, in particolare, i temi relativi alla tolleranza dei giovani e quelli riferiti alla tolleranza all'interno della società democratica.

Parole chiave: tolleranza, storia 